\title{
都市内公共交通機関の運行本数からみた 仙台市のデイリー・リズム
}

\section{谷 貝}

等

\section{Iはじめに}

機能の地域分化の著しい現代の都市において， 人は自己の目的を達成するために地区間の移動 を余儀なくされる。そして，個人の移動行動に よって各地区の滞留人口構成の変化が生じる結 果，都市は 1 日を通してその姿を時々刻々と変 容させていく。中でも 1 日において最も顕著な 移動行動である通勤は，居住地と就業地とを往 復する通勤者によって，毎日の規則正しい都市 の「呼吸」を生ぜしめている。このような都市 の動態的側面を把握するために，1日（24時間） における地域機能の時間変化と, その変化をも たらす人間・財などの地区間移動の連続的変化 を明らかにするデイリー・リズム daily rhythmの研究が注目されるようになったので ある。

1 日において 1 サイクルの活動が完結する閉 鎖システムとして都市をとらえるならば，日常 的都市システムと対応した通勤圏を範囲とする 2 次元空間に，1日の長さの時間軸を加えるこ とによって，1都市・1 日を基本単位とした座 標空間の設定が可能であろう。そこで，デイ リー・リズムをはじめとしたこのような時・空 間において展開する諸現象を扱うために，
Thrift ら゙は, 社会システムにおける4つの分析 レベルを提示している。すなわち，上位レベル から下位レベルに向かって，1）上部構造 superstructure, 2) 物理的.環境 physical environment, 3）活動システム activity system, 4) 態度 - 知覚 attitude and perception が列挙され，下位レベルは上位レベルに包 括される。これらの中で，最下位に位置する態 度・知覚レベルに含まれる経験や意志決定は, 空間に直接投影される空間的移動を対象とした 活動システムにおいて具現される。また, 活動 システムは, たとえば商店の営業時間や交通機 関の運行ダイヤのような物理的環境から制約が 加えられている。最上位の上部構造は, 政治経 済全般に関連して社会構造の基礎を成すもので あるが，活動システム以下のレベルへは間接的 な影響を及ぼすに留まるであろう。

デイリー・リズムに関する研究は, 活動シス テム・レベルによるものが中心となり，個人単 位の研究と集計された段階での研究とに分ける ことができる。まず，最も基本となる不可分な 個人を単位とした研究では，座標空間内にデイ リー・パス daily pathを描いて議論される。 わが国においては，農村地域を対象とした研究 が活発で，たとえば自宅と農地間の毎日の往復

1）鈴木栄太郎「近代化と市民組織」，都市問題44-10，1953，1347-1356頁。

2) Parkes, D. and Thrift, N., 'Putting time in its place', in Carlstein, T., Parkes, D. and Thrift, N. eds., Timing Space and Spacing Time Vol. 1 : Making Sense of Time, Edward Arnold, 1978, pp. 119-129.

Thrift, N., 'Time and theory in human geography Part I', Progress in Human Geography 1, 1977, pp. 65-101.

3）たとえば，大杉 昇「山村に扔ける高齢者の生活行動とその空間的パターン一広島県戸河内町の事例一」, 地理科学 42 一 2, 1987, 82-95頁。高橋伸夫・市南文一「出島村における生活行動に関する地理学的研究」, 霞ヶ浦地域研究報告 3 , 1981, 57-76頁。 
によるデイリー・リズムや病院への通院といっ たウィークリー・リズム weekly rhythm が明 らかにされている。しかし, 個人単位での研究 においては，デイリー・パスの記述に留まるこ となく，行動選択に関する合理的解釈を行い, さらには上位レベルの物理的環境や上部構造と の相互関連を扱う時間地理学の枠組みを利用し た議論が要求されよう。

一方, 集計された段階での研究においては, 個人の属性，1 日における時刻，空間上の位置 の 3 点が関心の対象となっている。そこでは, まず，夜間に抢ける居住の側面のみを扱ってき た従来の因子生態研究の 1 日（24時間）への拡 張が試みられる。しかし，センサス類では時間 帯別のデー夕を揃えることができないため，こ れを試みるには独自の調査が必要とされる。そ こで, Taylor and Parkesは, 現実データの不 足を補うために仮想デー夕を用いながらも，1 日を通した因子生態の解明の重要性を示し，デ イリー・リズム研究への道を開いた。その分析 方法としては，従来の因子生態研究で用いられ てきた〈地区 $\times$ 属性〉行列の因子分析を拡張し て，〈時・空間 $\times$ 属性〉行列の因子分析が用い
られた。この方法を現実デー夕に適用した研究 によれば，「社会経済的地位」と「家族的地位」 の因子生態研究における 2 大因子の他に，平日 における 1 日の都市活動を反映した，デイ リー・リズム研究に特有の因子が上位因子とし て抽出されている。

しかしながら，範疇の異なる時間と空間を同 一次元として扱った因子分析法の適用には疑問 がもたれる。それゆえ，連続的な時間変化の側 面を強調して，各単位地区における属性別人口 集団毎の滞留人口の 1 日の変化から, 人口構成 の時間変化が明らかにされている。こうした滞 留人口の時間変化は, 各単位地区に立地する施 設の機能によって説明されていることから，都 市全体からみた各単位地区の機能や地区間の相 互作用と関連させて，人間の空間的移動の側面 から総合的に説明を加える必要があるであろう。

滞留人口の変化を生起させる人間の空間的移 動を分析対象とするならば, OD デー夕を用い て，地区間結合のデイリー・リズムを明らかに することが考えられる。パーソン・トリップ調 查を利用して，直接的連結法により備後都市圈 における中心地体系の時間変化を明らかにした

4）櫛谷圭司「時間地理学 (Time-geography) の内房漁師の行動選択の解釈への応用」，地理評58一10，1985，645一 662 頁。

5）時間地理学に関しては，以下のものを参照されたい。

(1) 櫛谷圭司「時間地理学研究の動向」, 人文地理 $37-6,1985,533$-551頁。

(2) Thrift, N., An Introduction to Time Geography: Concepts and Techniques in Modern Geography 13, Geo Abstracts, Norwich, 1977, 36p.

6) Taylor, P. J. and Parkes, D. N., 'A Kantian view of the city : a factorial-ecology experiment in space and time', $E n$ vironment and Planning A 7, 1975, pp. 671-688.

7） (1) 若林芳樹「時間・空間に扔ける広島都市圏の因子生態分析」，地理評60-7，1987，431一454頁。

(2) Goodchild, M. F. and Janelle, D. G., 'The city around the clock : space-time patterns of urban ecological structure', Environment and Planning A 16,1984, pp. 807-820.

8） Taylor and Parkes〔注 6〕が用いたデータを利用し，MDS（多次元尺度構成法）や 3 相因子分析といった異なる手法 により導かれた結果を比較したものとして，以下の研究が上げられる。

Hanham, R. Q., 'Factorial ecology in space and time : an alternative method', Environment and Planning A 8, 1976, pp. 823-828.

Langlois, A., 'Les transformations de l'espace social de la ville : une application de l'analyse factorielle a trois entrées', Canadian Geographer 27, 1983, pp. 67-73.

9）(1)小方 登「都市内部時空間における人口・活動分布の分析一姫路市と大阪市を例として一」，奈良大学紀要 $12 ， 1983$ 105-121頁。

(2) 小方 登「都市内部時空間の因子生態一姫路市の人口のデイリー・リズム—」，人文地理 $37-1 ， 1985 ， 1-19$ 頁。

(3) Janelle, D. and Goodchild, M., 'Diurnal patterns of social group distributions in a Canadian city', Economic Geography 59, 1983, pp. 403-425. 
若林の研究は, 都市圏全体のデイリー・リズム を，帯留人口に基づく因子生態のデイリー・リ ズム研究において言及され得ない地区間の空間 的組織の面から統一的に説明している。同様に, 自動車 OD 調査を利用して, 東京23区の機能 地域のデイリー・リズムを明らかにした伊藤の 研究では，業務目的の交通量が多いことから， 業務関連の機能地域構造が強調される結果とな っている。しかしながら, 活動システム・レベ ルの集計された段階におけるデイリー・リズム 研究は, 上記のように利用可能なデータが限ら れているため, 調査データが入手不能な地域で は研究できない点が大きな障害となっている。 次に, 態度・知覚レベルの研究においては, Lynch が都市内部のイメージ研究における時 間次元の重要性を指摘し, 都市内地区の時刻別 イメージの図化を試みている。都市内エレメン 卜に対するイメージの 1 日における遷移過程を 明らかにした Tranter and Parkes の研究によ れば，午前と午後よりも昼夜による差異の大き いことが明確にされた。上記のような都市のイ メージ研究は, 活動システムへの影響と共に, 環境設計への応用が大きな目的とされている。 このように，物理的環境は，活動システムに対 して直接的な制約の機能を果たすのみならず, 人間の知覚を通して間接的な影響をも与えてい るのである。

それゆえここで物理的環境の重要性を改め て強調する必要があろう。物理的環境を構成す る各要素は, 日々規則正しい活動を行うための pacemaker として作用し，人間行動に制約を もたらしている。たとえば，蔡が扱った商店の 営業時間は, 従業員の勤務時間を決定し, 消費 者の買物行動にも時間的制約を加え, pacemakerとしての役割を果している。このよう な制約を通して人間行動を解釈する時間地理学 的観点は, 選択された結果としての行動を分析 する従来の行動地理学に対して, その選択肢を 提示し，行動の遂行されるに至った過程を説明 することにより, 行動の本質へのさらに深い理 解を可能とさせるものである〔注 5 ) -(2)p. 33〕。

ところで, 都市における人間の移動行動を制 約する公共交通機関は, 毎日の規則正しい運行 によって，都市のデイリー・リズムを生み出す 重要な要素であると考えられる。そこで本稿は， 上記のような都市のデイリー・リズムに関する 研究動向をふまえて, 都市内における人間の空 間的移動を制約する公共交通機関の運行本数の 時間変化から, 都市のデイリー・リズムを明ら かにすることを目的とする。したがって，本稿 は，物理的環境レベルの範疇の移動に関するデ イリー・リズムの研究として位置づけられる。 また，従来，データをパーソン・トリップ調査 などの大規模な調査に求めてきた都市のデイ リー・リズムの研究に対して, 公共交通機関の 運行という新たな側面からのアプローチは, データの不足がさけばれるこの研究分野の要請 にも応えることになるのである。

10）若林芳樹「備後都市圏における中心地の日単位での活動リズム」（西村睦男・森川 洋編『中心地研究の展開』，大明堂， 1986)，250-264頁。

11）伊藤 悟「自動車交通流からみた東京都区部における機能地域のディリー・リズム」，人文地理 $35-5 ， 1983 ， 385-405$ 頁。

12) Lynch, K., What Time is This Place?, MIT Press, 1972, 東京大学大谷研究室訳『時間の中の都市』, 鹿島出版会, 1974，371+16頁。

13） Lynch, K., Managing the Sense of a Region, MIT Press, 1976, 北原理雄訳『知覚環境の計画』, 鹿島出版会, 1979, 108-184頁。

14) Tranter, P. and Parkes, D., 'Time and images in urban space', Area 11, 1979, pp. 115-120.

15) Parkes, D. N. and Thrift, N., 'Timing space and spacing time', Environment and Planning A 7, 1975, pp. 651-670.

16）蔡 文彩「台北大都市地域西部における機能活動のディリーリズム」(高野史男編著『都市形成の地理的基盤』，大明堂， 1980)，184-199頁。 
II 対象地域の概要と近接性の測定方法

（1）対象地域の概要 都市内公共交通機関の 運行本数を指標としてネットワーク分析を行う ため，本稿では，次のような条件のもとに，東 北地方の広域中心都市である仙台市を研究対象 都市とした。1）公共交通機関の利用率が高い
と考えられる県庁所在地レベル以上の人口規模 を有する都市であること。2）きめ細かなサー ビスを行うため，運行本数の時間変化が大きく 現れるバス交通の発達している都市であること。 3 ）他の都市からの独立性が強い都市であるこ と。1）と 2 ）の条件に関して確認するならば, 仙台市は，通勤通学目的に利用される交通手段

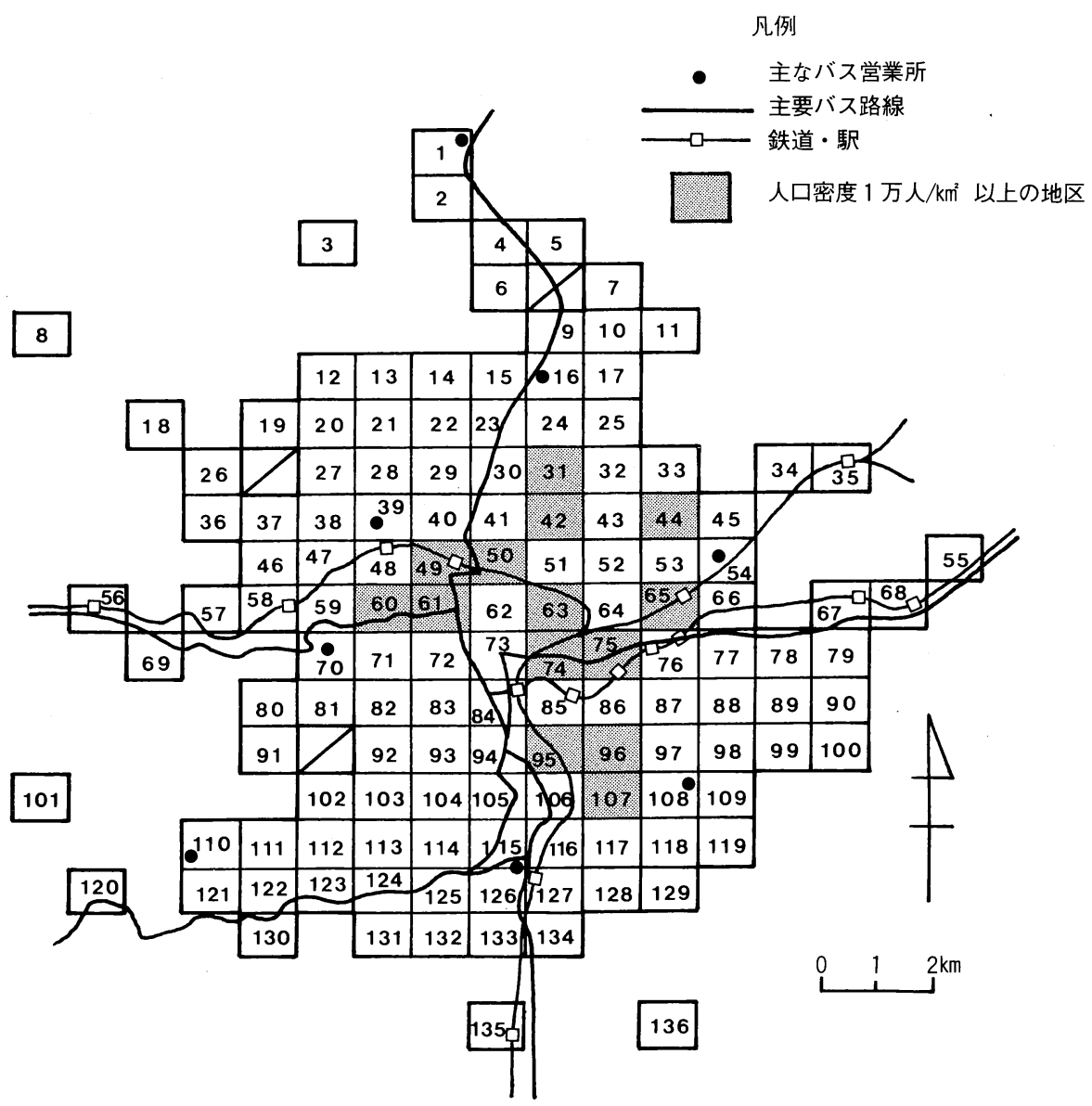

主なバス営業所（1・110は宮城交通，その他は仙台市交通局）

1. 泉(営) 16. 七北田(営) 39. 北仙台(営) 54. 東仙台(営) 70. 川内(営) 108. 霞の目(営) 110. 仙台(営)(山田自由ケ丘車庫) 115. 長町(営)

主な停留所

21. 宮城学院前 35. 岩切駅前 44. 鶴ケ谷中央 49. 北仙台駅 56. 落合 59. 八幡神社前

67. 福田町 72. 市役所. 交通局前 76. 原町駅前 80. 宮教大前 84. 仙台駅前

104. 八木山神社前 123. 鈎取 129. 飯田三ッ橋 135. 南仙台駅

第 1 図 対象地域と単位地区

Fig. 1 Study area and unit areas

資料: 昭和 55 年度国勢調査 
のうち，鉄道とバスの利用率が高い大都市の中 でも，バス利用率は $30.2 \%$ と高率を示している。 また，仙台市の都心に集中する通勤交通のうち， 公共交通機関の利用率は約60\%（鉄道16.3\%, バス43.1\%) を占めている。

対象地域は，仙台市の人口集中地区に加え， バス路線を考慮して, $\mathrm{CBD}$ とのつながりが強 い郊外住宅団地までを含む範囲とした。ノード として扱う単位地区（以下単に「地区」と称す） は，対象地域内に均等に分布することが望まし いため，総理府統計局の基準メッシュに従い， 136地区を設定した（第 1 図）。

仙台市の地域概要は，以下のようにまとめる ことができる。仙台駅の西側地域 [単位地区番

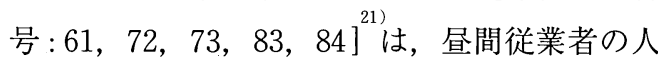
口密度が 1 万人 $/ \mathrm{km}^{2}$ を越え, 県庁・市役 所・中心商店街が立地する CBD に相当する。 一方, 夜間人口は, $\mathrm{CBD}$ を取り囲む旧市街地 において 1 万人 $/ \mathrm{km}^{2}$ 以上の人口密度（第 1 図) $)^{23)}$ となっており, この地域は，昼間人口も $\mathrm{CBD}$ に次いで多いことから，職住混在の人口 稠密地域を形成していると考えられる。さらに その外側には住宅団地が広がり, 特に北部から 南西部にかけての丘陵地においては宅地造成が 盛んで，高等学校や大学の移転・新設も多い。 また，仙台駅より東側の国道 4 号線バイパス沿 いには，計画的な東部工業団地 $[67,77,78$, 79，88，89，90，99，100] が整備され, 北部 には泉パークタウン流通団地 [2] が造成中で
ある。

仙台市の公共交通機関は，鉄道が主に都市間 の中・長距離交通を分担する一方，市内交通と しては，仙台市交通局と宮城交通によるバス交 通が中心的役割を果たしている。また，仙台市 交通局と宮城交通の一部路線とその他の民営バ スによる周辺市町村への運行は，鉄道路線同様 に，市内においては，市内交通の一翼を担って いる。バス路線は，ほとんどの運行が市役所・ 交通局 [72］と仙台駅 [84] を始発，または通 過する一点集中型である。仙台駅 [84] から南 北に南仙台［135］と七北田［9］方面へ延び る国道 4 号線，原町 [76] を通り塩釜へ向かう 国道45号線，八幡神社 [59] を通り山形方面へ の国道48号線, さらに長町 [115] から秋保温 泉方面への国道286号線が主要路線となってい る(第 1 図)。また，人口密度の高い地域におい て効率的な運行を行うため, ほとんどの営業所 は，対象地域縁辺の住宅地に配置されている (第 1 図)。

( 2 )近接性の測定方法 本稿で対象とする公 共交通機関は，対象地域内において平日 1 日に 運行される全ての鉄道とバスである。そここで, 5 ２2時台までを 1 時間毎に18の時間帯に分け, 各々の時間帯に対して運行本数を指標としたネ ットワーク分析を行い，ネットワーク全体に対 する個々の地区の近接性を求めた。それぞれの 運行は, 対象地域内での運行時間が短いことか ら，起点における始発時刻に代表させて各時間

17）総理府統計局編『昭和55年国勢調査資料シリーズ No. 3 従業地・通学地』，1983，538一 545頁，から算出したところに よると, 通勤通学者のバス利用率が $30 \%$ を越える人口 30 万上の都市は, 仙台市の他に福岡市 $(30.5 \%)$, 長崎市 $(38.5 \%)$ ，那覇市 $(32.2 \%)$ の 3 市である。

18）仙台都市圈総合都市交通計画協議会事務局『仙台都市圈の人の動き一第 2 回パーソントリップ調查から一』, 1983,15 頁。

19）郊外住宅団地においては，団地単位にバス路線が引かれているため，各団地毎に単位地区を設定した。

20）仙台に関する研究成果は, 次の文献にまとめられている。 田辺健一・長谷川典男編著『実験都市仙台一都市地理学研究の課題一』，大明堂，1982，273頁。

21）以下同様に, 対応する単位地区番号は [ ] 内に示される。なお, 地域名称に対しては, 代表する単位地区番号のみを 示している場合がある。

22）昭和56年度事業所統計調査のメッシュ・データによる。

23）昭和55年度国勢調査のメッシュ・データによる。

24） 1986年 7 月平日における運行ダイヤを利用した。 
帯への振り分けを行った。また，対象地域外が 始発となる運行は，対象地域内に初めて入った 時刻を始発時刻とした。なお，対象とする公共 交通機関の運行の約 $95 \%$ をバスが占めるため, 本稿では，バスの運行を中心に考察を加えるこ とにする。

鉄道やバスの交通網のネットワーク分析を行 った従来の研究においては, 地区間結合の強さ を明らかにするために，最短時間や運行本数を 指標とした対称有值行列が取り上げられてきた。 本稿では，1 日の 1 時間帯毎における公共交通 機関の運行本数を指標として取り上げ，運行の 上り・下りの区別をも考慮に入れるため，行方 向に出発地区，列方向に到着地区をとった非対 称な有向有值行列の分析を行うことにする。有 向有值行列を用いることにより，出発と到着の 2 側面からみた近接性の測定が可能となる。

また，乗り換えを考慮した近接性の演算に関 する従来の方法では，過剩パスを多く含み，求 められた近接性の值は非現実的であった。公共 交通機関を扱う場合，利用者の利用状況に見合 った方法による近接性の算出が望まれる。そこ で，利用者は，1）仙台市においては，1 回乗 り換えを行うことにより市内のほとんどの地区 へ到達が可能であることから，2 回以上乗り換 えはしない，2）目的地へ直接到達できる運行 があるならば，乗り換えを行うルートは選択し ない，という2つの仮定から，乗り換えによる 摩擦を重視した以下の方法で近接性の算出を行 っだ。
まず，行方向に出発地区，列方向に到着地区 をとり，直接運行のある地区間の行列要素には 実際の運行本数を記入し，その他の行列要素は $「 0 」 と し た 〈 136$ 地区 $\times 136$ 地区〉の運行本数 行列 $\boldsymbol{L}$ を18の時間帯毎に作成する。その際, 対角要素には「0」を記入する。次に，1回乗 り換えを考慮した運行本数行列 $\boldsymbol{L}^{2}$ を求め, $\boldsymbol{L}$ と $\boldsymbol{L}^{2}$ とを加えた $\boldsymbol{T}$ を近接性行列として扱うこ とにする。ただし， $\boldsymbol{L}^{2}$ は，乗り換えを行わず 直接到達できることを重視するため, 従来の方 法のようにすべての行列要素に対してではなく， $\boldsymbol{L}$ において直接結合のない「0」の記入されて いる行列要素に対してのみ，以下の式における $\ell_{i j}$ を記入し, 対角要素とその他の行列要素は

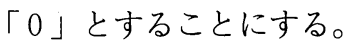

$$
\begin{aligned}
l_{i j}=1 / \min & \left\{\left(1 / l_{i k}\right)+\left(1 / l_{k j}\right)\right\} \\
& (k=1,2,3, \cdots, 136 ; i \neq j)
\end{aligned}
$$

$l_{i j}: i$ 地区から $j$ 地区への 1 回

乗り換えによる近接性

$l_{i k}: i$ 地区から $k$ 地区への運行本数

$l_{k j}: k$ 地区から $j$ 地区への運行本数

この $l_{i j}$ は, $i$ 地区を出発して 1 回乗り換え を行い $j$ 地区に到達する際に， 1 時間当たりの 運行本数の逆数で示される待ち時間の和が最小 となるような $k$ 地区において乗り換えを行う ルートを選択すると仮定した上で，その待ち時 間の和の逆数をとって再び運行本数に換算した 値と同值である。

ここにおいて，各地区の近接性は，近接性行 列 $\boldsymbol{T}$ における行和・列和で定義し，それぞれ

25）伊藤 悟「長野県中信地域におけるバス交通ネットワークの時空間構造とその変化一1962 1982年一」，金沢大学教育 学部紀要 (人文科学・社会科学編) $35,1986,21$-40頁。

牛久保浩一「バス交通による神奈川県中央部の結節システムの変化」，人文地理 $38-4 ， 1986 ， 360$ - 376 頁。 小方 登「都市内公共輸送網のネットワーク分析一京都市営バスを例として一」, 人文地理 $32-6,1980,493$ 一 503 頁。 郭 金水「バス交通ネットワークからみた松本市に㧍ける近接性と結節体系」, 地域調査報告 7，1985，101一109頁。 葛谷明子「中京圈における交通ネットワーク分析」，人文地理32-6，1980，481-492頁。

26）奥野隆史・高森 寛『点と線の世界: ネットワーク分析』，三共出版，1976，33一69頁。

Taaffe, E. J. and Gauthier, H. L., Geography of Transportation, Prentice-Hall, 1973, 奥野隆史訳『地域交通論一その空 間モデル—』，大明堂，1975，126一-167頁。

27）たとえば， $t$ 時台において $a$ 地区から $b$ 地区を経由して $c$ 地区へ $n$ 本のバスまたは鉄道が運行されているとすると， $t$ 時台における運行本数行列 $\boldsymbol{L}$ には, $a$ 行 $b$ 列・ $a$ 行 $c$ 列・ $b$ 行 $c$ 列にそれぞれ $n$ が記入される。 
を出発の近接性・到着の近接性とする。すなわ ち, 出発の近接性は 1 つの時間帯（1時間に相 当）の間に当該地区から出発する運行により到 達可能な延べ地区数を表し, 同様に到達の近接 性は 1 つの時間帯の間に到達する運行により当 該地区に到達可能な延べ地区数を表している。 ここで求められた近接性は, ネットワークに基 づく測度であると共に，延べ地区数を意味する 点において累積機会による測度と類似しており， 村山が定義した立地的有利性を示すポテンシャ ル・アクセシビリティとして解釈できよう。ま た，ネットワーク分析は18の時間帯毎に行うが, 対象地域が同一であり，かつ指標は運行本数と いう絶対数であることから, 近接性の值の各時 間帯間の絶対的比較が可能である。

\section{III 近接性の空間的分布の時間変化}

本章は, 各時間帯における近接性の空間的分 布の 1 日を通しての変容過程を明らかにするこ とを目的とする。出発と到着の近接性の空間的 分布を図示することにより，各時間帯における 近接性の絶対量の分布状況が明らかになる。さ らに, 両者を比較すると, 出発と到着の近接性 のいずれが卓越するかによって，人口の流出入 に関する各地区の機能的特性が理解できるであ ろう。

対象とする鉄道とバスの 1 時間毎の運行本数 の時間変化（第 2 図）によると, 平日において は， 7 時台と 17 時台に 2 つの明瞭なピークが認 められる。これは, パーソン・トリップ調査の 結果による通勤通学と帰宅トリップのピークに 相当している[注18）16-17頁〕また，土曜日に 流, 郊外住宅地内に所在する学校を経由するバ

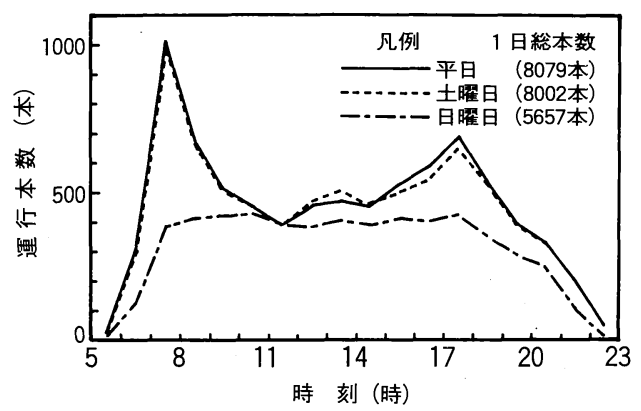

第 2 図 1 時間毎の運行本数の時間変化

Fig. 2 Temporal variation of number of services per hour

資料: 仙台市営バス・宮城交通バス時刻表（1986年 7 月現 在)，時刻表1986年 7 月号

ス路線の運行本数が, 平日と比べて15〜18時台 に減少し，12〜13時台には増加している。この ことから, 学校終業時に合わせてバスが運行さ れていると考えられる。日曜日には，平日のよ うな朝夕の通勤通学と帰宅に伴う運行の増加が みられず， 7 ～17時台は，ほぼ一定の本数で運 行されている。そこで, 平日においては，通勤 通学と帰宅の時間に基づいて，18の時間帯を次 の 6 つの時間帯にまとめることが可能であろう。

1 早朝の時間帯 $(5 \sim 6$ 時台) 運行本数の 少ない 6 時台における近接性の分布をみると (第 3 図(A)), 出発の近接性は, 南北の国道 4 号 線に沿った地区 [ 9，15，16，23，30，41，50, 94，106，115] において高く $(350 \sim 650)^{30)}$, そ の他に各営業所から $\mathrm{CBD}$ 一向かう出庫路線上 の地区 [39, 54, 108, 110,115] での近接性 が高い（250～500)。また, CBD から離れた北 部と南西部の各住宅団地 $[1,4,5,110$, 111，121，122]は，6時台においてすでに朝 のピーク時に近い出発の近接性（200～350）を 記録することから，これら縁辺地域では 7 時前

28) Pirie, G. H., 'Measuring accessibility : a review and proposal', Environment and Planning A 11, 1979, pp. 299-312, で 分類した (1) 距離測度, (2) トポロジカルな測度, (3) 重力測度, (4) 累積機会に基づく測度を, 土谷敏治「累積機会に基づ く測度によるアクセシビリティの測定」, 人文地理 $38-3 ， 1986,265-280$ 頁，は(1)ネットワークに基づく測度，(2) ポ テンシャル測度, (3) 累積機会に基づく測度の 3 つにまとめている。

29）村山祐司「日常的行動に基づく居住地のポテンシャル・アクセシビリティ」，人文地理 $34-1 ， 1982 ， 21-34$ 頁。

30）以下, 近接性の值は，（）内に示される。 


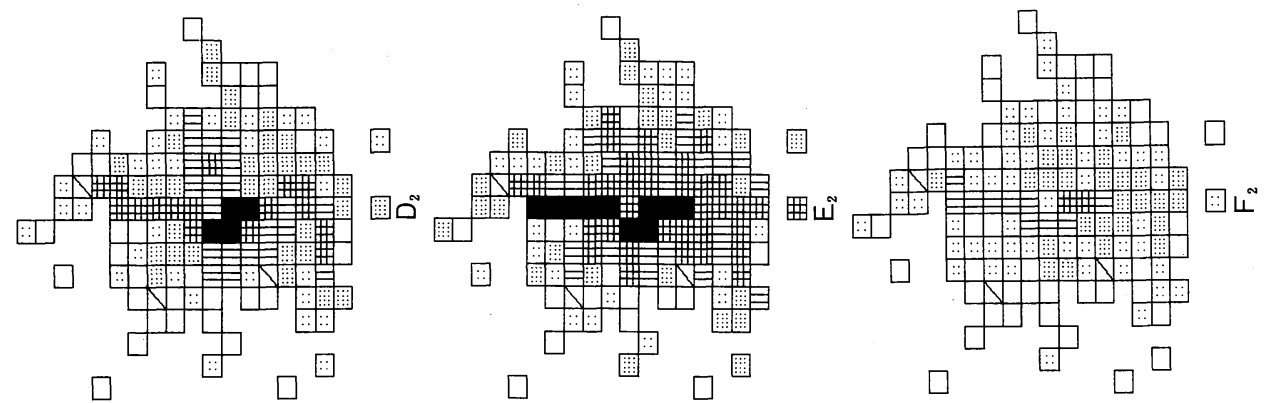

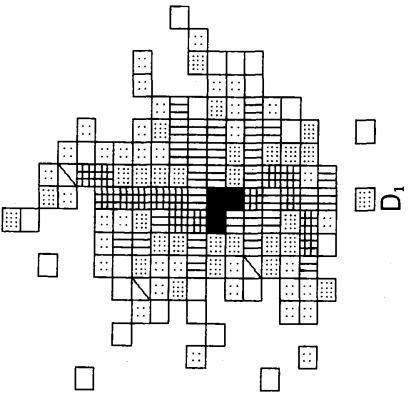

$\square$

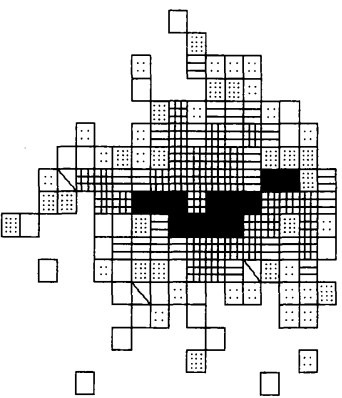

$\square$

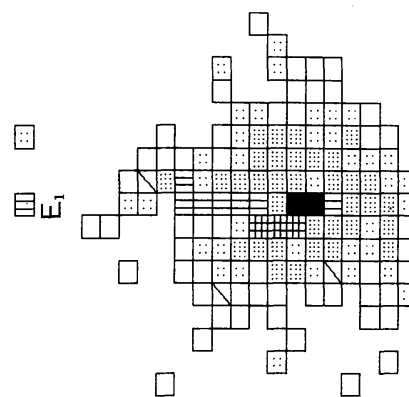

呑

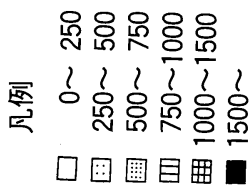

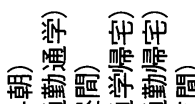

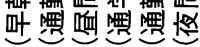

웅용요

ใरदे?

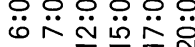

$\ddot{\varangle} \ddot{\oplus} \ddot{0} \ddot{0} \ddot{\omega} \ddot{~}$
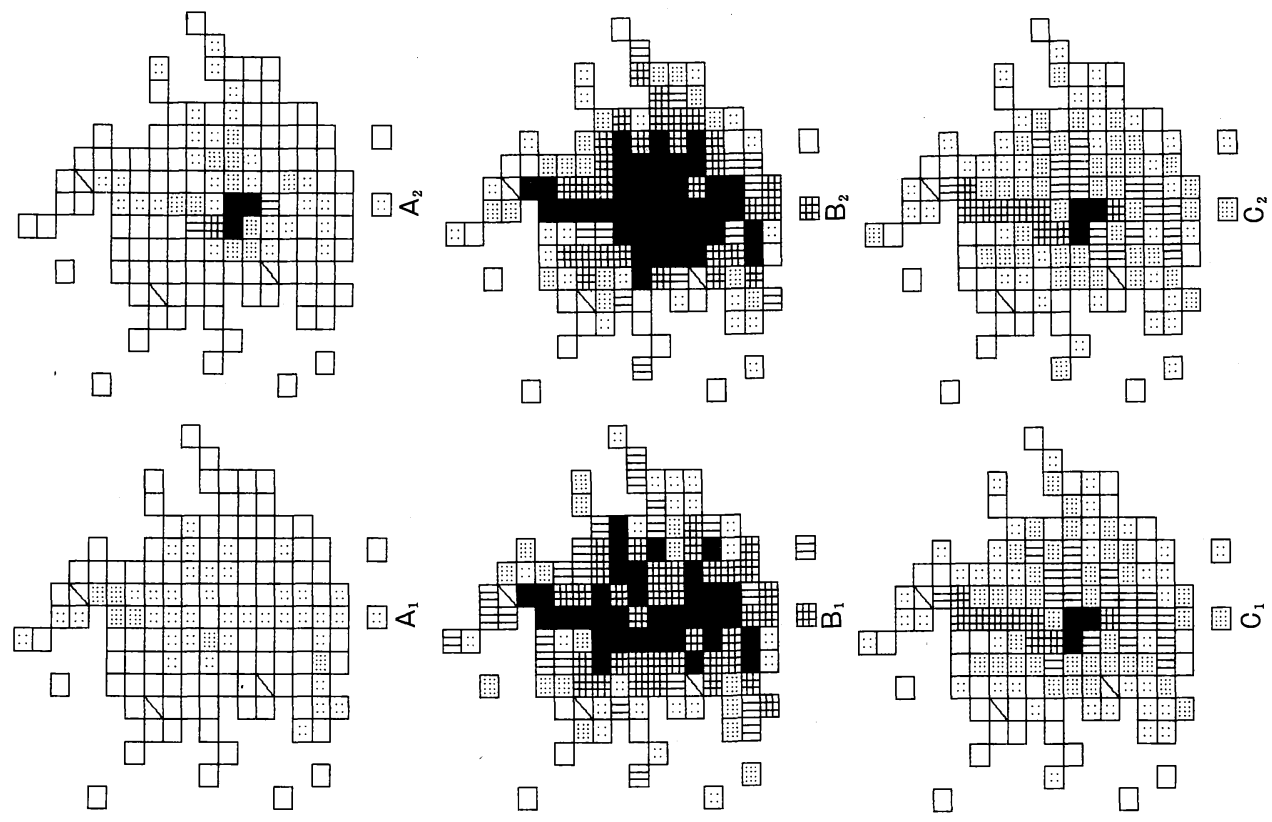
から通勤通学に伴う運行が開始されるものと推 測される。到着の近接性は，鉄道とバスの $\mathrm{CBD}$ へ「集中」を反映して, CBD [72，73， 84]において極端に高い（1600～2200)。

2 通勤通学の時間帯（7 9 時台）この時 間帯は，1日の中で最も運行本数が多く，公共 交通機関を利用した移動行動が活発な時間帯で ある。そこで, 昼間の 2 倍以上の 1,010 本の鉄 道とバスが運行され, 運行本数が朝のピークと なる 7 時台の近接性を第 3 図 (B) に示す。出発 の近接性は，南北に走る国道 4 号線を軸として， 各営業所 [39，54，108] から CBD へ向かう 路線沿いの地区において高い（1500～1800）。到 着の近接性は, $\mathrm{CBD}$ を頂点 $(4500$ ５500）とし て同心円状に低下し，国道 4 号線に沿って近接 性の高い地区（1500～2500）が連なる。1日を 通して近接性がそれほど高くない学校所在地区 [21，37，81] と東部工業団地においても到着 の近接性は高く，出発の近接性を上回っている。 これは，仙台駅 [84] からこれらの地区への通 勤通学に伴う運行が多いことを反映するもので ある。

3 昼間の時間帯（10１4 時台） 昼間の時間 帯においては，出発と到着の近接性の差は小さ く，時間変化の少ない安定した近接性の分布パ ターンを示す。これは，業務・買物・帰宅とい った雑多な移動目的（注18）16一17頁〕に応えるた め，等間隔で上り・下りが運行されるためであ る。12時台における近接性の分布（第 3 図 (C) によると，この時間帯においても，主要路線上 の地区での近接性が高くなっている（750～ 1300)。東部工業団地と縁辺地域の住宅団地で は，近接性は低い（500以下）。昼間の時間帯は, 近接性が比較的安定して变化は少ないが，それ でも 1 時間毎に朝から夕方の近接性の分布パ ターンへ漸次移行していく。

4 通学帰宅の時間帯（15 16時台） 15時に なると, 北西部の学校所在地区 $[21,27,37$,
46]において，直前の昼間の時間帯より出発の 近接性が高く（200～500増加）なり，学校終業 時に合わせてバスが運行されていることを示し ている（第 3 図(D)）。また，夕方の通勤者の帰 宅のピーク時に備え，各営業所から $\mathrm{CBD}$ 一向 けての運行が始まることから, 主要路線に沿っ て出発の近接性が高く（750１000）なり, CBD においては，到着の近接性が高まる（2100～ 2600)。しかし，その他の地区では昼間の時間 帯と比べて近接性の大きな変化はない。

5 通勤帰宅の時間帯（17 18 時台） 通勤者 の帰宅が始まる17時台における出発と到着の近 接性（第 3 図(E)）は，7時台とは逆に, CBD からの運行の「分散」を反映したパターンを示 す。出発の近接性は, CBD から各方面への㷌 宅に対応して中心部で高まる（2900～3400）も のの, 帰宅は, 朝の通勤通学に比べて前後の時 間に分散するため, 出発の近接性は 7 時台にお けるピークより低い。到着の近接性は，主要路 線沿いの地区で高くなっている（1000１700）。 帰宅に伴う運行は17時台がピークとなり，18時 台からは減少傾向となる。

6 夜間の時間帯（19 22時台）この時間帯 は，前の時間帯の帰宅の状況を保持しながら， 対象地域の縁辺部, 人口稠密地域, 主要路線沿 いの地区の順に近接性は時間を追って低下して いく。20時台における近接性の分布（第 3 図 (F)）によると, 出発の近接性は, 対象地域の縁 辺部でかなり低下している (250以下)。到着の 近接性は, CBD から営業所までの地区と主要 路線沿いの地区でやや高くなっている（400〜 900）のみである。そこで, CBD から 1 回乗り

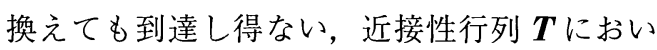
て CBD からの近接性が「0」である地区数を みると，20時台までは昼間とほぼ同数の 4 地区 であるが，21時台には13地区となり，22時台に なると44地区に増加する。同様に，CBD 以外 の各地区についても近接性が「0」になる地区 
数を調べると，22時台には, 主要路線沿いの地 区を除いて，ほとんどの地区において到達し得 ない地区数が100を越えている。このように， 22時台には CBD から各営業所方面への限られ た運行のみとなるため, 仙台市内の公共交通機 関の運行は21時台でほぼ終了すると考えられる。

以上, 通勤通学と帰宅に伴う運行を中心とし て，1 日における18の時間帯を $6 つ の$ 時間帯に まとめ, 近接性の空間的分布の時間变化を検討 した。その結果，対象地域の近接性は運行本数 の時間変化に従って単純に全域的に増減するの みでなく，1日を通して近接性の分布パターン が6つの時間帯に基づきリズミカルに変化して いることが明らかになった。

\section{IV 近接性の時間変化パターンの地域特性}

前章では, 各時間帯毎の近接性の空間的分布 から，公共交通機関の運行状況の 1 日の変化過 程を考察した。本章では，時間帯間の近接性の 絶対量による比較が可能である点を生かして, 各地区の 1 日における近接性の時間変化パ夕ー
ンの類型化を行なう。さらに，各類型において， その近接性の変化パターンを生みだす要因を検 討することにする。

各地区に抒ける 5 ～22時台の出発と到着の近 接性の時間変化のグラフは，近接性の值の絶対 量による違いがみられるものの，朝夕の $2 つ の ~$ ピークをもつという点で運行本数の時間変化の 形と類似している（第 6 図 $\left(\mathrm{A}_{1}\right) \sim\left(\mathrm{E}_{1}\right)$ 参照）。 そこで, 出発の近接性と到着の近接性の差を発 生一吸収示数と定義して，当該地区の各時間带 毎の発生と吸収の度合いを示すことにする。各 地区毎に発生一吸収示数の時間変化を描いた発 生一吸収グラフを比較すると，それぞれのグラ フの形状に，いくつかの類似点が認められる。 そこで，これらの発生一吸収グラフを類型化す るため，次のようなクラスター分析を試みた。 すなわち，各時間帯における発生一吸収示数を 変数として, 〈136地区 $\times 18$ 変数〉の発生一吸収 示数行列を各変数毎に標準化した後，ユークリ ッド距離に基づくワード法によるクラスタリン グを行なった（第 4 図）。133ステップ以降は順

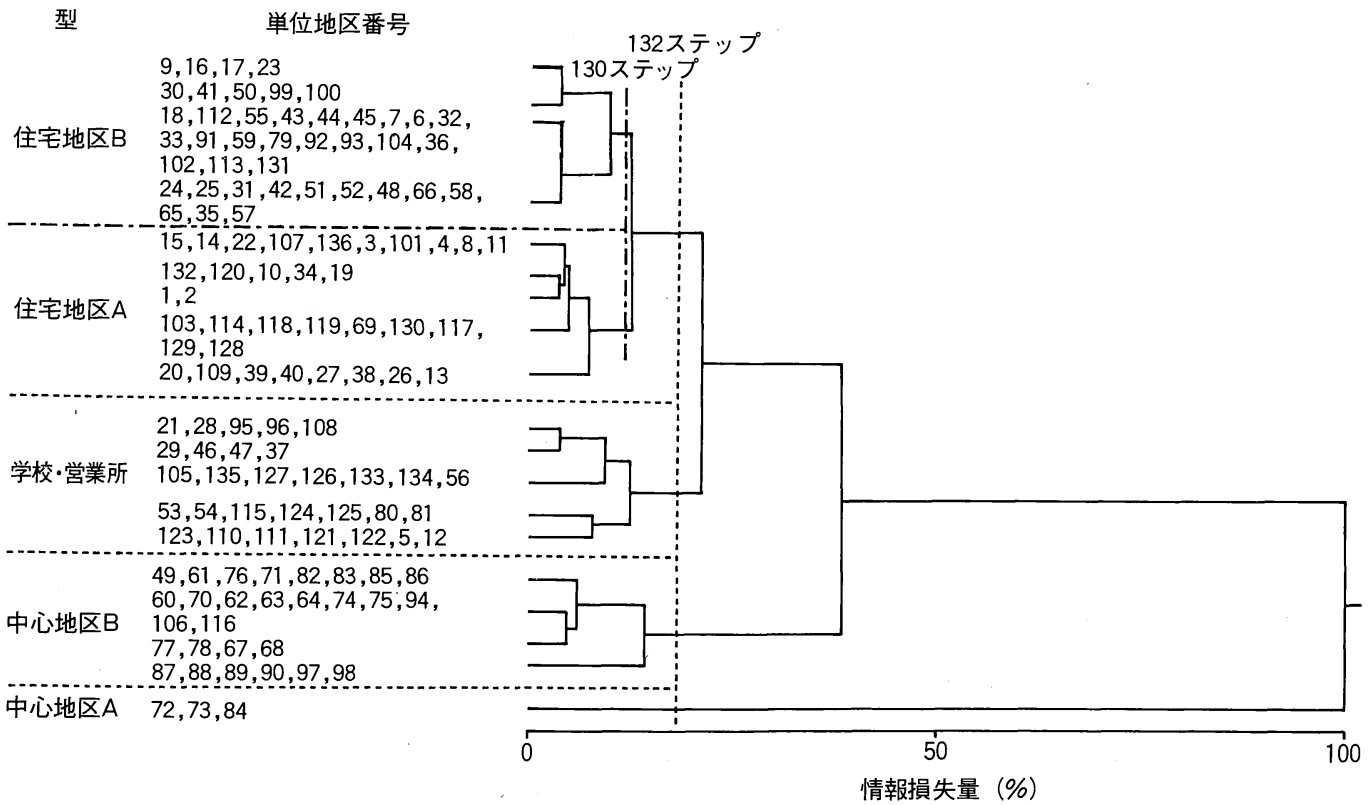

第 4 図＼cjkstart発生-吸収示数の時間変化パターンのグループ化のデンドログラム

Fig. 4 Dendrogram in terms of grouping temporal variation patterns of generation-pull index 
次クラスターが取り込まれて大きなクラスター を形成していき，かつ，情報損失量の増加も大 きくなることから，132ステップ終了後の状態 で 4 つの型に類型化した。しかし，住宅地区型 は含まれる地区数が多いため，130ステップに おいて住宅地区 $\mathrm{A} \cdot \mathrm{B}$ 型とに 2 分して合計 5 類 型とした。以下では，各型における発生一吸収 示数を, その構成要素となる各地区の発生一吸 収示数の平均值で代表させることによって，各 類型毎に近接性の時間变化パターンからみた地 域特性を明らかにしたい。

類型化された $5 つ の$ 型は，朝に吸収，夕方に 発生が生じる中心地区型，逆に朝に発生，夕方 に吸収が生じる住宅地区型とに大別される。そ して, 中心地区型は, 発生一吸収示数の絶対量 の多少により，中心地区 $\mathrm{A}$ 型と中心地区 $\mathrm{B}$ 型と に分けられる。住宅地区型のうち，通勤通学の 時間帯に吸収，通学者の帰宅の時間帯に発生が 生じる地区は，学校・営業所型として住宅地区 $\mathrm{A}$ ・ B 型から区別される。また，中心地区 $\mathrm{A}$ 型 が最後までクラスタリングされなかったのは， グラフの形状よりも，発生一吸収示数の絶対量 の相違が大きかったためと考えられる。

1 中心地区 $\mathrm{A}$ 型 中心地区 A 型は，仙台駅 の西側地域 [72，73，84] の CBD に相当し (第 5 図), 広島での研究 [注 7)-11〕において類 型化された都心地域に対応する。これらの地区 は，ほとんどの鉄道とバスの起終点になってい るため, 各方面からの運行が 1 点に集中してい る。したがって，1日を通しての近接性は，他 の地区を大きく上回っている。発生一吸収示数 (第 6 図 $\left(\mathrm{A}_{2}\right)$ ) は，午前中には 7 時台をピーク とした負の值を示す吸収状況となり，鉄道とバ スが CBDに「集中」していることを意味する。 $9 \sim 13$ 時台においては, 出発と到着の近接性は ほほ等しく，発生一吸収示数は， \pm 0 付近の值 をとる。14〜16時台の吸収は，学校所在地区か らの運行と，17時台における CBD からの運行

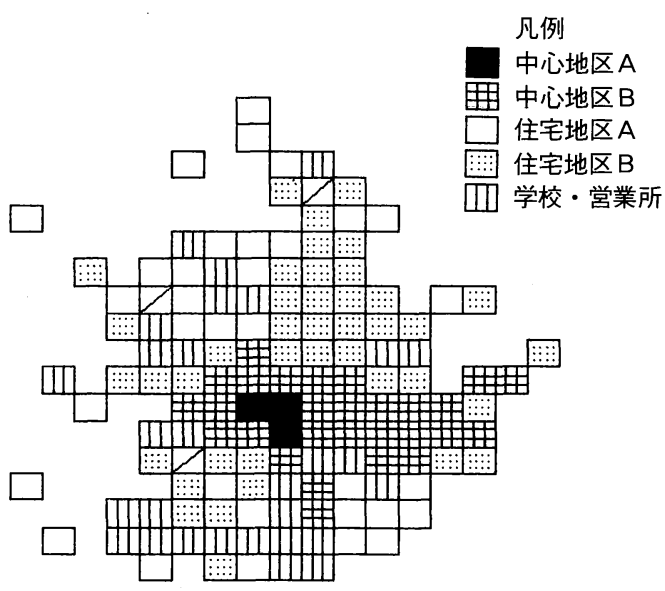

Ш

第 5 図 発生-吸収示数の時間变化パターンに基づく 地区類型

Fig. 5 Classification of unit areas based on tem poral variation patterns of generation-pull index

のための配車に関係する営業所からの運行によ るものと解釈できる。17時台になると，代わっ て CBD から各地区への運行の「分散」が顕著 になる。しかし，学生の帰宅が15～16時台に行 われることと，通勤者の帰宅時間が17時から夜 間まで延長されて幅を持つことから，夕方の発 生は朝の吸収ほどの強度は示さない。

2 中心地区 B 型 中心地区 B 型は，中心地 区 $\mathrm{A}$ 型と同様に朝に吸収，夕方に発生が顕著で あるが，発生一吸収示数の絶対量が少ない点に おいて相違する（第 6 図 $\left.\left(\mathrm{B}_{2}\right)\right)$ 。CBD を取り囲 む人口稠密地域と福田町 [67] ·長町 [115] 方面への主要路線沿いの地区，さらに東部工業 団地がこの型に相当する (第 5 図)。この中心地 区 B 型は，広島での研究〔注 7)一(1)における 商工住混在地区に対応し，中心地区 A 型と共に, 活動システム・レベルにおける研究との整合関 係が見られる。CBDに隣接する地区と主要路 線沿いの地区では，CBD と類似した運行パ ターンとなるため, 発生一吸収グラフは中心地 区型を示す。一方, 東部工業団地に関しては，1 日を通しての近接性は低いが，朝夕の発生一吸 

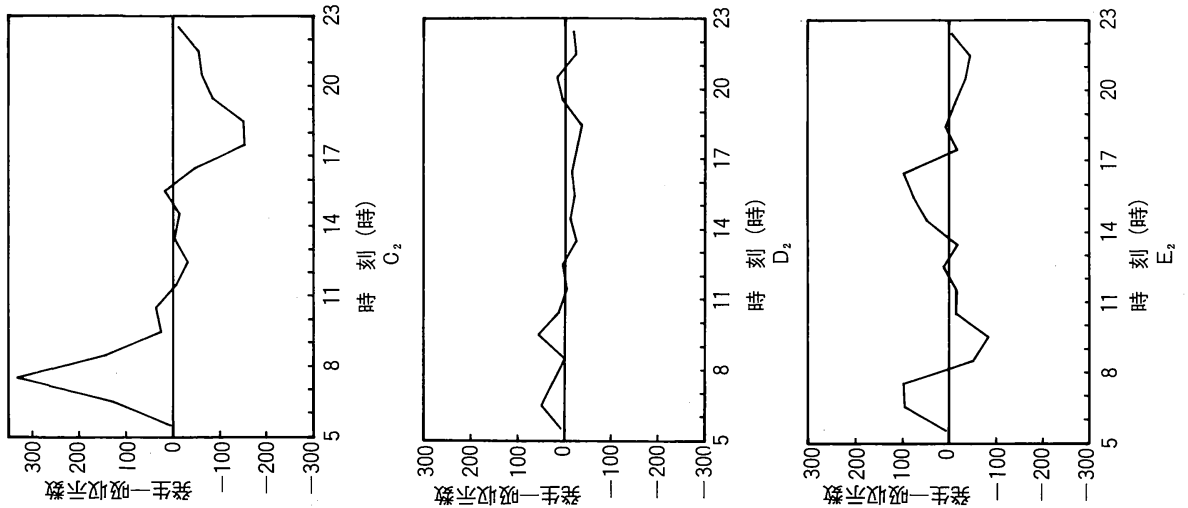

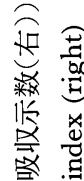
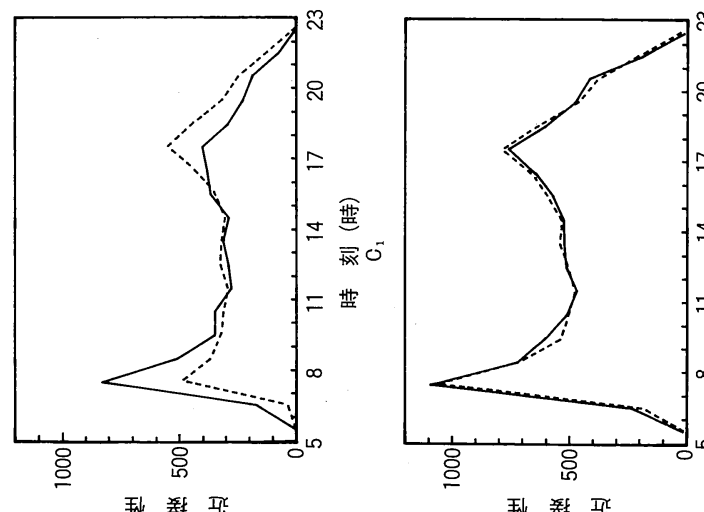

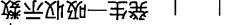
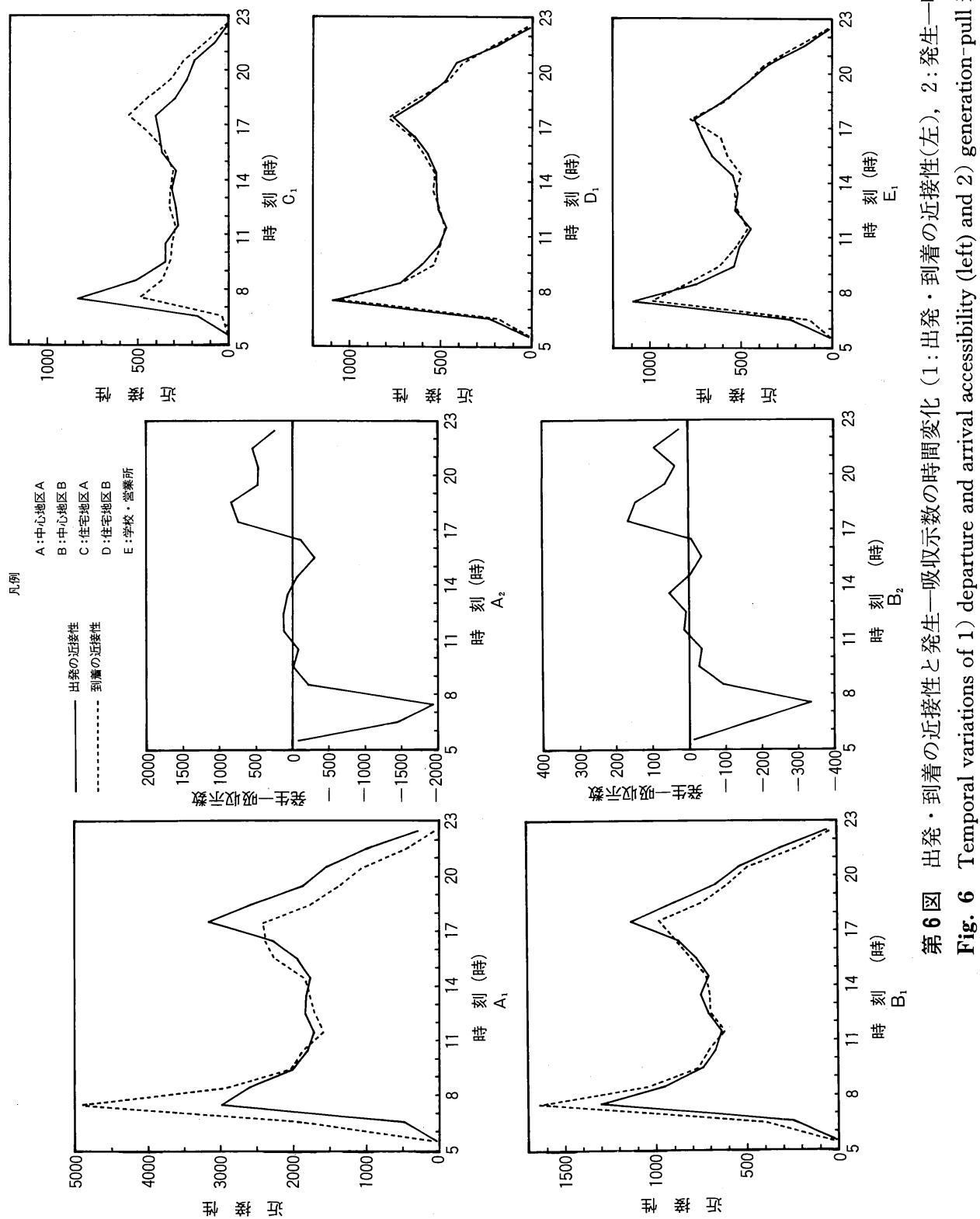
収示数のピークは明瞭で, 通勤と帰宅に合わせ た運行が行われ，昼間に人口を集める中心地区 型としての機能を有していることが理解される。

3 住宅地区 A - B 型 以上の中心地区型は, 姫路での研究〔注 9)一(2)〕における人口の「昼 間増加型」地区に対応するが，それに対置され る「昼間減少型」地区は，本稿においては，以 下に述べる住宅地区型に対応すると考えられる。 この型は, 朝に発生, 夕方に吸収が生じ, 中心 地区型と逆のパターンを示す（第 6 図 $\left(\mathrm{C}_{2}\right.$. $\left.\mathrm{D}_{2}\right)$ )。この型に含まれる地区数は, 75地区とか なり多いため，130ステップにおいてさらに2 つに細分し，それぞれ住宅地区 A・B 型とした。 住宅地区 $\mathrm{A}$ 型は, 朝に発生, 夕方に吸収が生じ る典型的な住宅地区型を示す。この型に含まれ る地区は, 将堅団地 [ 4，6] をはじめとする 北部から北西部の丘陵地において近年造成され た住宅団地と, 集落が点在する南東部の飯田三 ッ橋 [129] 方面（第 5 図）であり，1 日を通し て運行本数は少ないが, 通勤通学と帰宅に伴う 運行は確保されている。住宅地区 B 型は, 比較 的初期の昭和 40 年頃から入居が始まった鶴ヶ谷 [44] や八木山 [104] 等の人口稠密な住宅団地 に相当する(第 5 図)。そのため, 住宅地区 B 型 においては，1日を通して住宅地区 $\mathrm{A}$ 型より近 接性が高く, 循環路線の運行本数が多いことか ら，その発生一吸収グラフには朝の発生と夕方 の吸収が顕著に現れていない。

4 学校・営業所型この型では住宅地区 $\mathrm{A} \cdot \mathrm{B}$ 型と比べて 7 時台におけるピークが低く, $8 \sim 9$ 時台に吸収, 14〜16時台に発生が生じ, さらに17１8時台には吸収が生じない点が特徵 的である（第6 図 $\left.\left(\mathrm{E}_{2}\right)\right)$ 。この型に相当する地 区（第 5 図）は，住宅地の中に学校または営業 所が所在しているため, その機能の影響がこの 発生一吸収グラフに反映されているものと考え られる。すなわち， 7 時台において発生のピー クが低くなっているのは，学校始業時に合わせ
たバスの運行による吸収が, 通勤通学に伴う発 生を打ち消しているためである。8～9 時台は, バスが営業所へ帰庫するため，吸収状況を示す。 14時からは, 学校終業時に合わせて学校からの 運行が行われ, さらに, 営業所からは夕方の帰 宅ラッシュに備えて CBD へ運行がなされるた め, 発生の状況が強まる。17１8時台において は, 夜間まで運行する車両の営業所からの出庫 が吸収を打ち消し，夕方の吸収のピークは見ら れない。20２1時台は, 運行していた車両が順次 営業所入入庫するため, 到着の近接性が高まる。

\section{$\mathbf{V}$ ま め}

本稿は，都市のデイリー・リズムを明らかに することを目的とし，人間行動を制約する物理 的環境の中において，人間の空間的移動に大き く関わる公共交通機関を取り上げ，仙台市を事 例として，運行本数を指標としたネットワーク 分析による出発と到着の近接性の時間変化を検 討した。その結果，1 日を1 サイクルとした， 公共交通機関の運行に関する明暸なデイリー・ リズムが存在することが明らかになった。空間 的・時間的な近接性の変化パターンは以下のよ うにまとめられる。

1 ) 出発と到着の近接性の空間的分布の 1 日 の時間変化を追うと, 近接性の量的変化のみな らず, 分布パターンの質的変化がみられ, 対象 とする 5 22時台の18の時間帯は, 通勤通学と 帰宅に伴う運行に着目して6つの時間帯にまと められた。公共交通機関が動き始める早朝の時 間帯 ( $5 \sim 6$ 時台) から, $\mathrm{CBD}$ への運行の「集 中」が顕著な朝の通勤通学の時間帯 $(7 \sim 9$ 時 台）へは, 近接性が急激に増加する。その後, 昼間の時間帯（10１4時台）は, 雑多な移動目 的に応えるための等間隔運行により, 安定した 近接性の分布パターンを保つ。通学帰宅の時間 帯（15１6時台）においては, 営業所からのバ スの出庫と通学者の帰宅に伴う運行のために, 
営業所または学校が所在する地区からの出発の 近接性が高くなり，通勤帰宅の時間帯（17１8 時台）には, CBD からの運行の「分散」が行 われる。夜間の時間帯（19２2時台）は，この 「分散」パターンを保持しながら近接性が全域 的に徐々に低下し，21時台には，仙台市内の公 共交通機関の運行は主要路線を除いてほぼ終了 する。

2 ) 出発と到着の近接性の差をとった発生一 吸収示数の各単位地区における時間変化パ夕ー ンを, クラスター分析により 5 つの型に類型化 した。これらは，朝に吸収，夕方に発生が生じ る中心地区型と，逆に朝に発生，夕方に吸収が 生じる住宅地区型の 2 つに大きまとめられた。 中心地区型は, 発生一吸収示数の振幅が大きく, CBD に相当する中心地区 $\mathrm{A}$ 型と， CBD を取り 巻く職住混在の人口稠密地域と工業地域に相当 する中心地区 $\mathrm{B}$ 型とから成っている。一方，住 宅地区型は, 朝夕の発生一吸収示数の振幅の大 小により，住宅地区 A・B 型とに細分された。 学校・営業所型は, 住宅地に所在する学校や営 業所の影響により，8～9 時台に吸収，15１6 時台に発生が生じ，住宅地区型のパターンを乱 しているものである。

次に，以上の結果からバス特有の配車に関す る運行に伴う影響を除いて，公共交通機関の運 行からみた仙台市のデイリー・リズムを組み立 てることにする。7〜8時台を中心とする通勤 通学に伴って, 公共交通機関は, $\mathrm{CBD} \cdot$ 工業 地域・学校へ向けて運行される。等間隔に運行 される昼間の時間带を経て，14時からは，学校 終業時に合わせて学校からのバスの運行が行わ
れる。17時になると, $\mathrm{CBD} \cdot$ 工業地域から郊 外住宅地への通勤者の帰宅に伴う運行が顕著に なり，夜間は，この帰宅の状況を保持しながら 次第に運行本数が減少し，21時台で仙台市内の 公共交通機関の運行は，ほぼ終了する。かくし て，仙台市のデイリー・リズムは，朝の通勤通 学に伴う郊外住宅地から CBD への公共交通機 関の運行の「集中」と，夕方の帰宅による $\mathrm{CBD}$ から郊外住宅地への「分散」の「一呼吸」 により形成されていると要約されよう。その際, 朝の「集中」は一時的で強度なものであるが， 夕方の「分散」は，学校・就業地および自由活 動からの帰宅の時間帯が分散するため，15時か ら夜間まで持続する。このような都市における 「一呼吸」に関する結果は, 活動システム・レ ベルにおける移動行動を扱った備後都市圈での 研究結果 [注10] と一致している。

以上の結果と従来のデイリー・リズム研究の 成果を比較すると, 活動システム・レベルとそ れを制約する物理的環境レベルといった分析レ ベルや，滞留と移動といった分析対象の差異の 他に，対象とする都市の特性や，利用する指標 の違いによって，細部においてやや異なるデイ リー・リズムが組み立てられている。したがっ て, 時・空間を総体的に扱う分析手法が確立さ れていない現状を考えると，より一般的な都市 のデイリー・リズムの構築を図るためには, 様々な観点に立ったデイリー・リズム研究の蓄 積が必要とされるであろう。また，今後さらに 本研究の枠組みを発展させて，1日に打ける個 人のスケジュールの中で，その移動手段として の公共交通機関の利用可能性を追求するならば,

31) Forer, P. C. and Kivell, H., 'Space-time budgets, public transport, and spatial choice', Environment and Planning $A$ 13, 1981, pp. 497-509.

Lenntorp, B., 'Paths in space-time environments : a time-geographic study of movement possibilities of individuals', Lund Studies in Geography Series B 44, 1976, 150p.

Lenntorp, B., 'A time-geographic simulation model of individual activity programmes', in Carlstein, T., Parkes, D. and Thrift, N. eds., Timing Space and Spacing Time Vol. 2 : Human Activity and Time Geography, Edward Arnold, 1978, pp. 162-180.

Miller, R., 'Household activity patterns in nineteenth-century suburbs : a time-geographic exploration', A. A. A. G. 72, 1982, pp. 355-371. 
個人の日々の行動形成や都市のプランニングの 面への応用が期待されよう。

〔付記〕本稿を作成するに当たり, 親身に御指 導下さいました杉浦芳夫先生, 若林芳樹先生をは じめとする東京都立大学地理学教室の方々に深く 感謝いたします。また，貴重な御助言を頂きまし た宮城学院女子大学の阿部 隆先生, 快く資料を 提示して下さいました仙台市交通局総務部企画調
查室, 仙台市総務局企画部調査統計課, 仙台都市 科学研究会, 宮城交通㑣営業部営業課の方々に心 から御礼申し上げます。

本稿は, 1986年度東京都立大学理学部地理学教 室に提出した卒業論文をもとに，加筆・修正を施 したものである。なお，計算に当たっては東京都 立大学電算機センターを利用した。

（東京都立大学・院） 